\title{
Peningkatan Hasil Belajar Matematika Melalui Penerapan Metode Discovery Pada Peserta Didik Kelas IV SD Negeri 04 Wanggarasi
}

\author{
Mejlitha Kumendong \\ SD Negeri 04 Wanggarasi \\ mejlithakumendong@gmail.com
}

Received: 17 March 2021; Revised: 16 June 2021; Accepted: 28 August 2021
DOI: http://dx.doi.org/10.37905/aksara.7.3.895-906.2021

\begin{abstract}
Abstrak
Penelitian ini bertujuan untuk mengetahui apakah metode discovery dapat meningkatkan hasil belajar matematika pada peserta didik kelas IV SD Negeri 04 Wanggarasi. Jenis penelitian ini adalah penelitian tindakan kelas. Desain penelitian tindakan kelas yang digunakan adalah desain Kemmis dan Mc Taggart yang terdiri dari empat tahap yaitu perencanaan, tindakan, observasi, dan refleksi. Subjek penelitian adalah siswa kelas IV SD Negeri 04 wanggarasi yang berjumlah 16 orang. Tujuan dari penelitian ini adalah untuk mengetahui peningkatan hasil belajar matematika melalui penerapan metode discovery pada peserta didik kelas IV SD Negeri 04 Wanggarasi. Pengumpulan data dalam penelitian ini dilakukan dengan observasi dan tes Penelitian Tindakan Kelas (PTK) ini dikatakan berhasil apabila siswa kelas IV SD Negeri 04 Wanggarasi yang mencapai KKM minimal $75 \%$. Pembelajaran menerapkan metode discovery dengan guru menempelkan gambar di papan tulis dalam menjelaskan materi dapat meningkatkan hasil belajar peserta didik kelas IV SD Negeri 04 Wanggarasi pada mata pelajaran matematika. Pada pra tindakan persentase KKM peserta didik secara klasikal yaitu 25\%. Pada siklus I persentase KKM peserta didik secara klasikal sebanyak $50 \%$ yang berarti terjadi peningkatan sebesar $25 \%$ dari pra tindakan. Sedangkan pada siklus II persentase KKM peserta didik secara klasikal yaitu 87,50\% yang berarti terjadi peningkatan sebesar $37,50 \%$ dari siklus I dimana persentase tersebut telah mencapai target yang diinginkan yaitu minimal KKM peserta didik kelas IV SD Negeri 04 Wanggarasi secara klasikal adalah 75\%.
\end{abstract}

Kata kunci: Hasil Belajar, Pembelajaran Matematika di SD, Metode Discovery

\section{PENDAHULUAN}

Matematika merupakan mata pelajaran yang sulit dipahami sehingga siswa menjadi takut saat mendengar kata matematika (Antonius Cahya Prihandoko, 2006: 9). Oleh karena itu, penguasaan terhadap matematika harus diperlukan dan konsep-konsep matematika harus dipahami dengan betul dan benar sejak dini. Suatu konsep disusun berdasarkan konsep-konsep sebelumnya dan akan menjadi dasar bagi konsep-konsep selanjutnya, sehingga pemahaman yang salah dari suatu konsep akan berakibat pada kesalahan pemahaman terhadap konsep-konsep selanjutnya. 
Matematika harus disajikan dalam suasana yang menyenangkan sehingga peserta didik termotivasi untuk belajar matematika. Beberapa upaya yang dapat dilakukan guru untuk menarik perhatian dan meningkatkan motivasi siswa dalam belajar matematika antara lain dengan mengkaitkan materi yang disajikan dengan konteks kehidupan sehari-hari yang dikenal siswa di sekelilingnya atau dengan memberikan informasi manfaat materi yang sedang dipelajari bagi pengembangan kepribadian dan kemampuan siswa untuk menyelesaikan masalah-masalah selanjutnya, baik permasalahan dalam matematika itu sendiri, permasalahan dalam mata pelajaran lain, maupun permasalahan dalam kehidupan sehari-hari (Antonius Cahya Prihandoko 2006:10).

Keberhasilan proses pembelajaran ditentukan oleh hasil belajar yang dicapai oleh peserta didik Pembelajaran bukan menginformasikan materi agar dikuasai oleh peserta didik, tetapi memberikan kondisi agar peserta didik mengusahakan terjadi belajar dalam dirinya. Hasil belajar merupakan perubahan pada diri anak meliputi kemampuan intelektual, sikap/minat maupun keterampilan setelah mengikuti proses belajar mengajar. Kemampuan intelektual dapat diukur dengan tes hasil belajar. Peserta didik dapat dikatakan berhasil apabila telah mencapai Kriteria ketuntasan Minimal yang telah ditentukan pada mata pelajaran Matematika

Pada pelajaran matematika di kelas IV SD Negeri 04 Wanggarasi lebih ditekankan pada penguasaan materi supaya cepat selesai sehingga penggunaan metode ceramah lebih banyak dilakukan dan dipandang efektif untuk mencapai tujuan tersebut. Pembelajaran matematika hanya terfokus pada buku pelajaran, peran peserta didik hanya sebagai pendengar setia, kegiatan pembelajaran dimonopoli oleh guru, akibatnya keaktifan siswa menjadi kurang sehingga menyebabkan hasil belajar matematika lebih rendah jika dibandingkan dengan mata pelajaran yang lain. terutama pada materi membandingkan sudut dan mengukur sudut. Guru seharusnya memerlukan media pembelajaran yang akan di gunakan pada proses belajar mengajar agar konsep -konsep pelajaran yang disampaikan guru mudah menyerap

Agar proses pembelajaran itu dapat berlangsung dengan baik dan benar, dan peningkatan mutu pendidikan dapat terwujud maka permasalahan yang ada di sekolah harus dapat diselesaikan dan dibenahi. Untuk itu setiap guru dituntut untuk dapat menggunakan metode yang tepat, serta dapat membuat dan menyediakan media pembelajaran dalam pelaksanaan proses belajar mengajar. Salah satu metode pembelajaran yang dapat digunakan guru pada materi membandingkan sudut dan mengukur sudut adalah metode discovery. Metode ini dipilih karena memberikan kesempatan kepada setiap peserta didik untuk aktif berpartisipasi menemukan konsep melalui contoh-contoh konkret, gambar, dan informasi dari buku.

Diharapkan dengan penerapan metode discovery dan pemanfaatan media gambar pada pelajaran matematika maka pembelajaran matematika di SD dapat merangsang pikiran, perasaan, minat, serta perhatian siswa sedemikan rupa sehingga proses pembelajaran dapat terjadi dengan baik dan hasil belajarnya meningkat

\section{METODE}

Jenis penelitian ini adalah Penelitian Tindakan Kelas (PTK). Adapun langkah langkah rencana tindakan yang akan dilaksanakan dalam penelitian tindakan kelas adalah sebagai berikut : 


\section{Tahap Perencanaan Tindakan}

Tahap perencanaan dimulai dari penemuan masalah yang terjadi pada proses pembelajaran dan kemudian merancang tindakan yang akan dilakukan. Adapun persiapan yang akan dilakukan dalam penelitian ini adalah sebagai berikut :

a. Peneliti mengidentifikasi beberapa masalah dalam proses pembelajaran matematika di kelas IV.

b. Menentukan pembatasan materi yang akan diberikan.

c. Menentukan alat pengumpulan data yang digunakan untuk mengamati jalannya proses pembelajaran.

d. Menyusun Rencana Pelaksanaan Pembelajaran (RPP) yang memuat serangkaian kegiatan yang akan dilaksanakan dalam proses pembelajaran

e. Mempersiapkan alat peraga dan bahan yang akan dipergunakan dalam kegiatan pembelajaran.

f. Setelah penyusunan rencana penelitian dan sebelum melakukan pelaksanaan siklus I, terlebih dahulu peneliti melakukan pelaksanaan pra tindakan, yaitu dengan melaksanakan proses belajar mengajar seperti biasa tanpa adanya proses tindakan yang bertujuan untuk mengetahui nilai dari hasil belajar peserta didik sebelum dilakukannya tindakan.

\section{Tahap Pelaksanaan Tindakan}

Penelitian ini merupakan penelitian kolaboratif, sehingga pada tahap ini peneliti melaksanakan pembelajaran Matematika yang telah direncanakan sebelumnya dengan menggunakan metode discovery. Sementara itu teman sejawat melakukan observasi terhadap proses pembelajaran yang berlangsung menggunakan lembar observasi yang telah dibuat sebelumnya serta mendokumentasikan kegiatan pembelajaran yang sedang dilakukan. Pada setiap akhir siklus dilakukan pengambilan data tes evaluasi belajar.

\section{Tahap Observasi}

Observasi dilakukan pada saat proses pembelajaran berlangsung. Observasi ini digunakan untuk memperoleh data yang diperlukan dan untuk mengetahui sejauh mana hasil penerapan metode discovery dalam pelajaran matematika dengan berpedoman pada lembar observasi yang telah dipersiapkan sebelummnya. Pengamatan tersebut mencakup semua kegiatan yang dilakukan guru dan peserta didik selama proses pembelajaran matematika dengan media pembelajaran seperti suasana pembelajaran di dalam kelas, media pembelajaran yang digunakan, serta hambatan-hambatan yang dihadapi guru dan siswa selama proses pembelajaran berlangsung.

\section{Tahap Refleksi}

Data-data yang diperoleh selama proses pembelajaran dianalisa kemudian dilakukan refleksi terhadap proses pembelajaran yang telah dilakukan. Dalam tahap ini peneliti mengkaji, melihat dan mempertimbangkan dampak dari tindakan yang telah dilakukan. Hal ini dilakukan untuk mengetahui apakah tindakan yang telah dilakukan dapat direfleksikan kedalam tindakan selanjutnya agar pelaksanaan pembelajaran dengan menerapkan metode discovery dapat meningkat lagi. Apabila hasil yang diharapkan belum tercapai maka dapat dilakukan tindakan yang berbeda dengan mengulang tahaptahap siklus

Subjek dalam penelitian tindakan kelas ini adalah semua siswa kelas IV SD Negeri 04 Wanggarasi yang berjumlah 16 orang siswa yang terdiri dari 10 orang siswa laki-laki dan 6 orang siswa perempuan dan Obyek dalam penelitian ini adalah 
peningkatan hasil belajar matematika dengan menerapkan metode discovery pada siswa kelas IV SD Negeri 04 Wanggarasi tahun Pelajaran 2018/2019

Untuk mempermudah dalam pengumpulan data, peneliti menggunakan instrumen penelitian yang dilakukan dengan observasi yang dilakukan oleh seorang pengamat dan tes evaluasi belajar. Dalam penelitian ini, data penelitian ini dianalisis dengan data deskriptif kuantitatif teknik presentase yang memberi gambaran tentang penerapan media gambar dalam pelajaran matematika

$$
P=\frac{\sum \text { siswa yang tuntas belajar }}{\sum \text { siswa }} \times 100 \%
$$

Peneliti juga menganalisis dan mendeskripsikan bagaimana proses dan hasil pembelajaran matematika dengan menggunakan media gambar pada siklus I dan siklus II. Apabila terjadi peningkatan hasil belajar siswa terhadap pembelajaran matematika yang diketahui melalui hasil tes berarti hipotesis terbukti. Penelitian Tindakan Kelas (PTK) ini dikatakan berhasil apabila siswa kelas IV SD Negeri 04 Wanggarasi yang mencapai KKM minimal $75 \%$.

\section{HASIL PENELITIAN}

\section{Siklus I}

\section{Pra Tindakan (Pra Siklus)}

Dalam pelaksanaan pra tindakan metode yang digunakan oleh peneliti adalah metode ceramah dan tanya jawab. Pada tahap ini penggunaan media gambar belum dilaksanakan, pembelajaran ini dilakukan tanpa adanya proses tindakan. Sebelum memulai pelajaran terlebih dahulu guru mengadakan apersepsi dengan meminta peserta didik membandingkan sudut dan mengukur sudut kelas IV dengan menunjukkan berbagai macam benda untuk di sebutkan jumlah sudutnya. Kemudian guru menjelaskan materi dengan metode ceramah. Selanjutnya peserta didik bersama guru melakukan tanya jawab mengenai materi yang baru dijelaskan. Guru memberikan kesempatan kepada peserta didik untuk bertanya sekitar materi tetapi tidak ada peserta didik yang mengajukan pertanyaan. Peserta didik bersama guru menyimpulkan pelajaran. Pada akhir pelajaran, peserta didik diberi soal essay sebagai evaluasi, lalu guru bersama peserta didik membahas evaluasi. Kemudian guru memberikan pesan dan kesan kepada peserta didik. Pelajaran diakhiri dengan ucapan salam dari guru. Adapun nilai dari hasil evaluasi pra tindakan sebagai berikut :

Tabel 1

Hasil Nilai Pra Tindakan

\begin{tabular}{|c|l|c|c|}
\hline No & \multicolumn{1}{|c|}{ Nama Peserta Didik } & Nilai & Keterangan \\
\hline 1 & Abdul Kadir Abdjul & 40 & Belum Tuntas \\
\hline 2 & Alfian Laiji & 50 & Belum Tuntas \\
\hline 3 & Alan Hamid & 60 & Belum Tuntas \\
\hline 4 & Alwin Kaani & 45 & Belum Tuntas \\
\hline 5 & Muhlis Yusuf & 50 & Belum Tuntas \\
\hline 6 & Ismail Dunggio & 70 & Tuntas \\
\hline 7 & Ibrahim Halidu & 55 & Belum Tuntas \\
\hline 8 & Rahmat Tialo & 60 & Belum Tuntas \\
\hline 9 & Dirly Prasety Hamid & 50 & Belum Tuntas \\
\hline 10 & Firman Yusuf & 40 & Belum Tuntas \\
\hline
\end{tabular}




\begin{tabular}{|c|l|c|c|}
\hline 11 & Sri Rahmawati Tamau & 80 & Tuntas \\
\hline 12 & Sri Rahmawati Mantali & 70 & Tuntas \\
\hline 13 & Sin Zahro & 60 & Belum Tuntas \\
\hline 14 & Sulastri Abdullah & 50 & Belum Tuntas \\
\hline 15 & Ati Alisa Lamasika & 60 & Belum Tuntas \\
\hline 16 & Nurlela Monoarfa & 75 & Tuntas \\
\hline Jumlah & \multicolumn{2}{|c|}{57,19} \\
\hline \multicolumn{2}{|l|}{ Rata - rata } & \multicolumn{2}{|c|}{$25 \%$} \\
\hline \multicolumn{2}{|l}{ Ketuntasan Klasikal }
\end{tabular}

Berdasarkan tabel di atas dapat dianalisis sebagai berikut:

a) Pada pra tindakan yang telah mencapai kriteria keberhasilan yaitu baru 4 peserta didik (25\%), yaitu nilai sama atau lebih dari KKM 70

b) Pada pra tindakan terdapat 12 peserta didik (75\%) yang belum mencapai kriteria keberhasilan, yaitu nilai belum sesuai dengan KKM 70

Dengan kata lain, pada pra tindakan yang telah mencapai kriteria keberhasilan baru 25\% peserta didik dari 16 peserta didik kelas IV. Tentu saja hasil evaluasi tersebut masih menunjukkan angka yang belum cukup signifikan dan masih rendah karena belum $75 \%$ nilai yang sesuai dengan KKM yang diharapkan yaitu 70 (tujuh puluh), sehingga hasil belajar peserta didik tersebut perlu untuk ditingkatkan.

\section{Siklus I}

a. Perencanaan Tindakan

Perencanaan tindakan yang disusun merupakan rancangan pembelajaran matematika dengan menerapkan pembelajaran dengan metode discovery. Dalam pelaksanaan penelitian ini, peneliti berkolaborasi dengan teman sejawat. Tugas peneliti adalah melaksanakan pembelajaran matematika melalui metode discovery dan membimbing peserta didik agar dapat mengikuti pembelajaran dengan baik. Sedangkan tugas teman sejawat selama pembelajaran berlangsung adalah mengamati proses pembelajaran dan menuliskan hasil pengamatan pada lembar observasi yang telah disediakan

Perencanaan tindakan dimulai dengan menentukan materi matematika yaitu materi membandingkan sudut yang telah dilaksanakan pula dalam pra siklus. Setelah menentukan materi, selanjutnya adalah mempersiapkan instrument yang akan digunakan yaitu lembar observasi dan soal tes

Pada tiap akhir pertemuan dilakukan evaluasi untuk mengukur hasil belajar siswa setelah dilakukan tindakan. Setelah siklus I dilaksanakan, akan dilakukan refleksi untuk mengetahui kelebihan dan kekurangan selama pelaksanaan siklus. Apabila hasil yang diharapkan belum tercapai maka dapat dilakukan tindakan yang berbeda dengan mengulang tahap - tahap siklus I pada siklus II.

b. Pelaksanaan Tindakan

Guru mengawali pembelajaran dengan mengucapkan salam. Apersepsi dilakukan guru dengan bertanya jawab. Kemudian guru memotivasi peserta didik dan menjelaskan tujuan pembelajaran.

Pada tahap stimulasi, guru menayangkan beberapa gambar yang berhubungan dengan sudut. Pada tahap perumusan masalah, peserta didik dan guru bertanya jawab sehingga diperoleh sebuah rumusan permasalahan. Pada tahap pengumpulan data, setiap 
kelompok dibagikan LKS. Dengan berdiskusi peserta didik diminta mengumpulkan informasi/data untuk menjawab pertanyaan yang telah dirumuskan dari berbagai sumber. Guru berkeliling untuk melihat kegiatan peserta didik. Pada tahap analisis data, peserta didik berdiskusi untuk melakukan menganalisa masukan, tanggapan dan koreksi dari guru terkait pembelajaran tentang:

1) Mengolah informasi yang sudah dikumpulkan dari hasil kegiatan/pertemuan sebelumnya maupun hasil dari kegiatan mengamati dan kegiatan mengumpulkan informasi yang sedang berlangsung dengan bantuan pertanyaanpertanyaan pada lembar kerja.

2) Peserta didik mengerjakan beberapa soal mengenai membandingkan sudut

Tahap verifikasi dilakukan peserta didik dengan menuliskan jawaban di papan tulis. Guru menyebutkan nama kelompok maupun nama peserta didik yang mendapat tugas mengerjakan jawaban di papan tulis. Peserta didik lainnya memperhatikan jawaban dan mencocokkannya dengan jawaban yang telah di tulis pada LKS masingmasing kelompok.

Tahap generalisasi dilakukan peserta didik dengan bimbingan guru Kemudian guru bertanya kepada peserta didik apa ada materi yang kurang jelas. Peserta didik menjawab bahwa tidak ada. Kemudian peserta didik diminta mengumpulkan LKS.

Pada kegiatan akhir, guru mengadakan evaluasi untuk mengukur tingkat hsil belajar peserta didik terhadap materi yang telah diberikan dan membahas evaluasi bersama peserta didik. Setelah selesai dibahas bersama, guru meminta peserta didik mengumpulkan hasil pekerjaannya untuk dinilai. Kemudian peserta didik diberi kesempatan untuk menanyakan hal-hal yang belum dipahami. Guru memberikan penjelasan atas pertanyaan yang disampaikan oleh peserta didik. Peserta didik diminta melakukan refleksi terhadap proses pembelajaran terkait dengan penguasaan materi, pendekatan dan model pembelajaran yang digunakan Kemudian guru berpesan kepada siswa untuk mempelajari kembali materi yang dibahas pada setiap pertemuan dan membaca materi selanjutnya. Guru menutup pembelajaran dengan mengucapkan salam c. Observasi

Kegiatan observasi dilaksanakan dengan berpedoman pada lembar observasi yang telah disediakan oleh peneliti kepada observer. Untuk mencatat hal-hal yang tidak terekam oleh lembar observasi digunakan catatan lapangan. Hasil pengamatan selama proses pembelajaran pada siklus I

1) Observasi Terhadap Guru

Pengelolaan kelas oleh guru sudah dapat dikategorikan baik sekali karena guru sudah melaksanakan sebagian besar dari aspek - aspek yang ada pada lembar observasi, peserta didik agak bingung dalam memahami soal, tapi karena guru mengulang - ulang petunjuknya maka peserta didik menjadi mengerti tentang tugas yang harus mereka kerjakan dan mengerti tentang tugas mereka

2) Observasi Terhadap Peserta Didik

Pada pertemuan ini peserta didik sudah mulai antusias, hal ini terbukti pada perhatian peserta didik tertuju pada guru, peserta didik memperhatikan penjelasan dari guru dengan seksama, dan rasa senang peserta didik dalam menerima pelajaran dibuktikan dengan banyaknya peserta didik yang ingin maju mengerjakan soal di depan kelas. 
Secara umum, dalam pelaksanaan siklus I peserta didik mulai aktif ketika dilaksanakan metode pembelajaran dengan menampilkan media gambar di papan tulis. d. Refleksi

Adapun hasil refleksi yang dilakukan oleh peneliti terhadap penerapan metode discovery pada mata pelajaran matematika kelas IV SD Negeri 04 Wanggarasi berdasarkan data yang diperoleh selama siklus I, pembelajaran di kelas menunjukkan hasil yang sudah baik, karena rata-rata kelasnya sudah diatas KKM yang sudah ditetapkan di SD Negeri 04 Wanggarasi, yaitu diatas 70 (tujuh puluh).

Beberapa hal yang perlu ditingkatkan dalam siklus berikutnya antara lain:

1) Peserta didik belum begitu paham dengan berbagai macam sudut yang di jelaskan guru. Terbukti ketika diminta mengerjakan tugas peserta didik masih banyak bertanya mengenai sudut. Sehingga pada pertemuan berikutnya guru harus menjelaskan lebih detail lagi.

2) Peserta didik belum begitu paham dengan sudut satuan. Sehingga ketika mengerjakan soal mayoritas salah dalam menjawab pertanyaan berkaitan dengan sudut satuan. Hal ini karena sudut satuan yang dalam mengukur. Pada pertemuan berikutnya guru harus menyamakan sudut satuan yang dibuat siswa.

Tabel 2

Hasil Nilai Siklus I

\begin{tabular}{|c|l|c|c|}
\hline No & \multicolumn{1}{|c|}{ Nama Siswa } & Nilai & Keterangan \\
\hline 1 & Abdul Kadir Abdjul & 60 & Belum Tuntas \\
\hline 2 & Alfian Laiji & 55 & Belum Tuntas \\
\hline 3 & Alan Hamid & 60 & Belum Tuntas \\
\hline 4 & Alwin Kaani & 50 & Belum Tuntas \\
\hline 5 & Muhlis Yusuf & 55 & Belum Tuntas \\
\hline 6 & Ismail Dunggio & 85 & Tuntas \\
\hline 7 & Ibrahim Halidu & 75 & Tuntas \\
\hline 8 & Rahmat Tialo & 65 & Belum Tuntas \\
\hline 9 & Dirly Prasety Hamid & 70 & Tuntas \\
\hline 10 & Firman Yusuf & 60 & Belum Tuntas \\
\hline 11 & Sri Rahmawati Tamau & 80 & Tuntas \\
\hline 12 & Sri Rahmawati Mantali & 85 & Tuntas \\
\hline 13 & Sin Zahro & 70 & Tuntas \\
\hline 14 & Sulastri Abdullah & 60 & Belum Tuntas \\
\hline 15 & Ati Alisa Lamasika & 90 & Tuntas \\
\hline 16 & Nurlela Monoarfa & 80 & Tuntas \\
\hline Jumlah & \multicolumn{2}{|c|}{68,7100} \\
\hline Rata - rata & \multicolumn{2}{|c}{$50 \%$} \\
\hline Ketuntasan Klasikal & \multicolumn{2}{|c|}{} \\
\hline
\end{tabular}

Berdasarkan tabel di atas dapat dianalisis sebagai berikut:

a. Pada siklus I terdapat 8 siswa (50\%) yang telah mencapai kriteria keberhasilan, yaitu nilai sama atau lebih dari KKM 70

b. Pada siklus I terdapat 8 siswa (50\%) yang belum mencapai kriteria keberhasilan, yaitu nilai belum sesuai dengan KKM 70 
Dengan kata lain, pada siklus I yang telah mencapai kriteria keberhasilan baru 50\% siswa dari 16 siswa kelas IV. Tentu saja hasil evaluasi tersebut masih menunjukkan angka yang belum cukup signifikan dan masih rendah karena belum $75 \%$ nilai yang sesuai dengan KKM yang diharapkan yaitu 70 (tujuh puluh), sehingga hasil belajar siswa tersebut perlu untuk ditingkatkan.

3. Siklus II

a. Perencanaan Tindakan

Perencanaan tindakan dipersiapkan untuk melanjutkan materi pada siklus I. Materi yang dipelajari pada siklus II ini adalah Mengukur sudut. Instrumen penelitian yang siapkan oleh peneliti untuk melaksanakan penelitian pada siklus II ini masih sama seperti yang digunakan pada siklus I yang berupa lembar observasi aktivitas siswa dan kinerja guru, soal tes berupa soal evaluasi yang diberikan pada tiap akhir pertemuan.

Peneliti juga mempersiapkan Rencana Pelaksanaan Pembelajaran (RPP) dan alat peraga yang akan digunakan dalam pembelajaran matematika berupa gambar-gambar sesuai materi sebagai lanjutan pada siklus I.

Pada pertemuan siklus II guru menjelaskan lebih detail lagi mengenai sudut. Guru juga menyamakan sudut satuan yang digunakan siswa supaya tidak terjadi perbedaan dalam membuat sudut satuan dengan cara pengukuran sudut satuan menggunakan busur derajat. Perbedaan perencanaan Siklus II ini terletak pada penambahan media gambar yang tadinya hanya berupa gambar-gambar sudut, pada siklus II ditambah gambar arah mata angin untuk menjelaskan tentang sudut sehingga susana di dalam kelas menjadi lebih terkesan dan siswa menjadi semakin paham dengan macam-macam sudut.

Metode pembelajaran yang digunakan oleh peneliti dalam pembelajaran tetap sama seperti pada siklus I yaitu metode ceramah dan tanya jawab yang dilanjutkan dengan penggunaan media gambar dalam pembelajaran.

b. Pelaksanaan Tindakan

Guru mengawali pembelajaran dengan mengucapkan salam. Apersepsi dilakukan guru dengan bertanya jawab. Kemudian guru memotivasi peserta didik dan menjelaskan tujuan pembelajaran.

Pada tahap stimulasi, guru menayangkan beberapa gambar yang berhubungan dengan sudut. Pada tahap perumusan masalah, peserta didik dan guru bertanya jawab sehingga diperoleh sebuah rumusan permasalahan. Pada tahap pengumpulan data, setiap kelompok dibagikan LKS. Dengan berdiskusi peserta didik diminta mengumpulkan informasi/data untuk menjawab pertanyaan yang telah dirumuskan dari berbagai sumber. Guru berkeliling untuk melihat kegiatan peserta didik. Pada tahap analisis data, peserta didik berdiskusi untuk melakukan menganalisa masukan, tanggapan dan koreksi dari guru terkait pembelajaran tentang:

1) Mengolah informasi yang sudah dikumpulkan dari hasil kegiatan/pertemuan sebelumnya maupun hasil dari kegiatan mengamati dan kegiatan mengumpulkan informasi yang sedang berlangsung dengan bantuan pertanyaanpertanyaan pada lembar kerja.

2) Peserta didik mengerjakan beberapa soal mengenai pengukuran sudut

Tahap verifikasi dilakukan peserta didik dengan menuliskan jawaban di papan tulis. Guru menyebutkan nama kelompok maupun nama peserta didik yang mendapat tugas mengerjakan jawaban di papan tulis. Peserta didik lainnya memperhatikan 
jawaban dan mencocokkannya dengan jawaban yang telah di tulis pada LKS masingmasing kelompok.

Tahap generalisasi dilakukan peserta didik dengan bimbingan guru Kemudian guru bertanya kepada peserta didik apa ada materi yang kurang jelas. Peserta didik menjawab bahwa tidak ada. Kemudian peserta didik diminta mengumpulkan LKS.

Pada kegiatan akhir, guru mengadakan evaluasi untuk mengukur tingkat hsil belajar peserta didik terhadap materi yang telah diberikan dan membahas evaluasi bersama peserta didik. Setelah selesai dibahas bersama, guru meminta peserta didik mengumpulkan hasil pekerjaannya untuk dinilai. Kemudian peserta didik diberi kesempatan untuk menanyakan hal-hal yang belum dipahami. Guru memberikan penjelasan atas pertanyaan yang disampaikan oleh peserta didik. Peserta didik diminta melakukan refleksi terhadap proses pembelajaran terkait dengan penguasaan materi, pendekatan dan model pembelajaran yang digunakan Kemudian guru berpesan kepada peserta didik untuk mempelajari kembali materi yang dibahas pada setiap pertemuan dan membaca materi selanjutnya. Guru menutup pembelajaran dengan mengucapkan salam

c. Observasi

Data yang diperoleh dari hasil pengamatan selama proses pembelajaran matematika dengan menerapkan metode discovery pada siklus II yaitu:

1) Observasi Terhadap Guru

Suasana kelas pada siklus II sangat mendukung untuk pelaksanaan pembelajaran. Guru menyampaikan materi dengan tidak hanya terpatok pada materi dibuku tapi juga disesuaikan dengan kondisi peserta didik, peserta didik diajak untuk memikirkan bersama sama sesuai dengan keadaan sekitar yang sering ditemui peserta didik sehingga suasana kelas menjadi menyenangkan.

2) Observasi Terhadap peserta didik

Pada siklus II ini sudah tidak ada peserta didik yang kebingungan lagi, semua peserta didik dapat mengerjakan soal dengan baik. Hasil belajar peserta didik mengalami peningkatan. Terlihat dari hasil evaluasi yang dilakukan pada tiap akhir pelajaran pada setiap pertemuan. Walaupun pada siklus pertama hasilnya kurang baik, namun pada siklus II terlihat peningkatan hasil belajar yang cukup tinggi.

Pada saat mengerjakan evaluasi semua peserta didik bersemangat, hal ini ditunjukkan dengan mereka mengerjakannya secara individu, tidak ada yang bertanya. Pada saat membahas evaluasi, peserta didik terlihat begitu antusias. Beberapa peserta didik menawarkan diri ketika membahas evaluasi dan peserta didik lain menanggapi dengan baik. Pada siklus II jelas terlihat keaktifan peserta didik jika dibandingkan dengan siklus I.

d. Refleksi

Hasil penelitian secara keseluruhan pada pembelajaran siklus II menunjukkan adanya peningkatan terhadap hasil belajar peserta didik yang dilihat melalui hasil tes peserta didik yang dilaksanakan tiap akhir pertemuan. Peningkatan keaktifan siswa juga terlihat dalam kegiatan pembelajaran dan antusias mereka. Hal tersebut menunjukkan adanya respon positif dari peserta didik dalam mengikuti pembelajaran matematika dengan menerapkan metode discovery 
Pembelajaran matematika dengan metdoe discovery dapat meningkatkan hasil belajar peserta didik di kelas IV SD Negeri 04 Wanggarasi, untuk lebih jelasnya lihat tabel berikut ini:

Tabel 3

Hasil Nilai Siklus II

\begin{tabular}{|c|l|c|c|}
\hline No & \multicolumn{1}{|c|}{ Nama Siswa } & Nilai & Keterangan \\
\hline 1 & Abdul Kadir Abdjul & 70 & Tuntas \\
\hline 2 & Alfian Laiji & 85 & Tuntas \\
\hline 3 & Alan Hamid & 80 & Tuntas \\
\hline 4 & Alwin Kaani & 60 & Belum Tuntas \\
\hline 5 & Muhlis Yusuf & 80 & Tuntas \\
\hline 6 & Ismail Dunggio & 85 & Tuntas \\
\hline 7 & Ibrahim Halidu & 80 & Tuntas \\
\hline 8 & Rahmat Tialo & 85 & Tuntas \\
\hline 9 & Dirly Prasety Hamid & 75 & Tuntas \\
\hline 10 & Firman Yusuf & 60 & Belum Tuntas \\
\hline 11 & Sri Rahmawati Tamau & 95 & Tuntas \\
\hline 12 & Sri Rahmawati Mantali & 100 & Tuntas \\
\hline 13 & Sin Zahro & 95 & Tuntas \\
\hline 14 & Sulastri Abdullah & 90 & Tuntas \\
\hline 15 & Ati Alisa Lamasika & 100 & Tuntas \\
\hline 16 & Nurlela Monoarfa & \multicolumn{2}{|c|}{83,75} \\
\hline Jumlah & $87,50 \%$ \\
\hline Rata - rata & \multicolumn{2}{|l|}{} \\
\hline Ketuntasan Klasikal &
\end{tabular}

Berdasarkan tabel di atas dapat dianalisis sebagai berikut:

1) Pada siklus II terdapat 14 peserta didik $(87,50 \%)$ yang nilai sama atau lebih dari KKM 70

2) Pada siklus II terdapat 2 peserta didik (12,50\%) belum mencapai kriteria keberhasilan, yaitu nilai belum mencapai KKM 70.00

Dengan kata lain, pada siklus II yang telah mencapai kriteria keberhasilan $87,50 \%$ peserta didik dari 16 siswa kelas IV. Penelitian ini dihentikan pada siklus II karena peneliti telah puas dengan hasil yang dicapai yaitu nilai mencapai atau lebih dari $75 \%$ nilai yang sesuai dengan KKM yang diharapkan yaitu 70

Berikut adalah diagram persentase KKM peserta didik antar siklus kelas IV SD Negeri 04 Wanggarasi dalam proses pembelajaran matematika materi membandingkan sudut dan pengukuran sudut: 


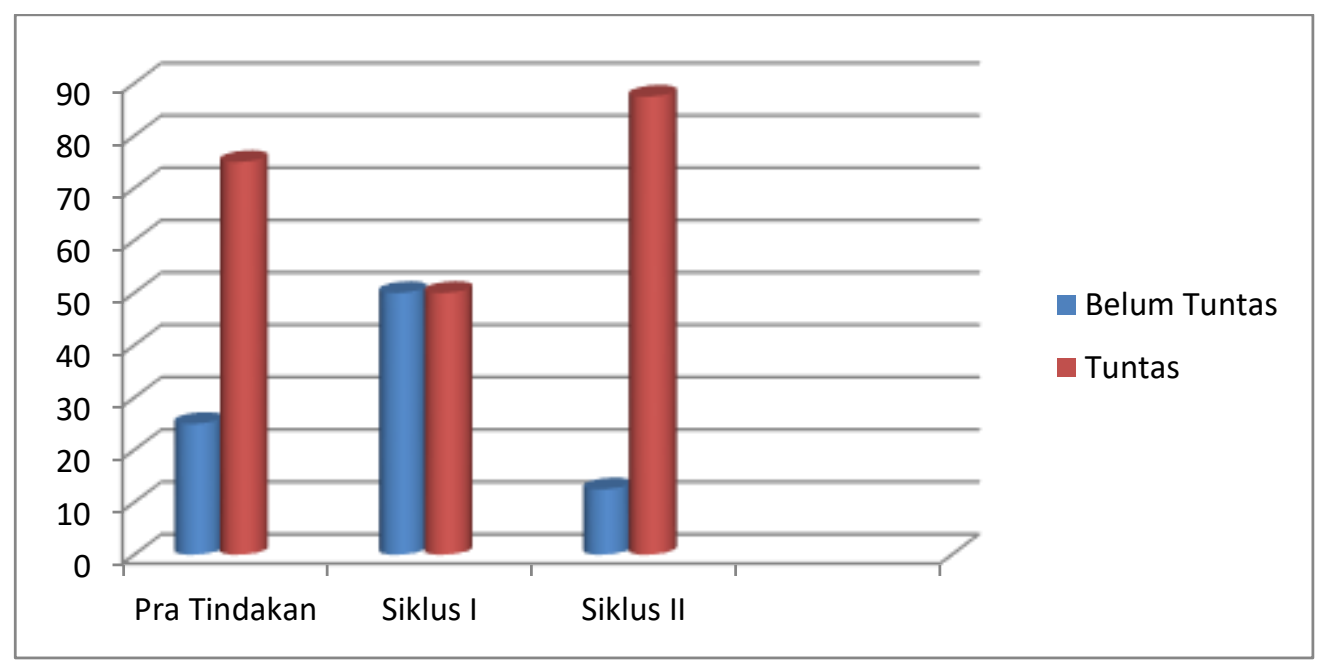

Gambar 1

Diagram Presentase Ketuntasan Klasikal tiap siklus

\section{PEMBAHASAN}

Secara umum, dalam pelaksanaan siklus I peserta didik mulai aktif ketika dilaksanakan model pembelajaran dengan menampilkan media gambar di papan tulis. Peserta didik sudah mulai antusias, hal ini terbukti pada perhatian peserta didik tertuju pada guru, peserta didik memperhatikan penjelasan dari guru dengan seksama, dan rasa senang peserta didik dalam menerima pelajaran dibuktikan dengan banyaknya peserta didik yang ingin maju mengerjakan soal di depan kelas. Hanya saja peserta didik belum begitu paham dengan berbagai macam sudut yang di jelaskan guru. Terbukti ketika diminta mengerjakan tugas peserta didik masih banyak bertanya mengenai sudut. Sehingga pada pertemuan berikutnya guru harus menjelaskan lebih detail lagi.

Pada pertemuan siklus II guru menjelaskan lebih detail lagi mengenai sudut. Guru juga menyamakan sudut satuan yang digunakan peserta didik supaya tidak terjadi perbedaan dalam membuat sudut satuan dengan cara pengukuran sudut satuan menggunakan busur derajat. Perbedaan perencanaan Siklus II ini terletak pada penambahan media gambar yang tadinya hanya berupa gambar-gambar sudut, pada siklus II ditambah gambar arah mata angin untuk menjelaskan tentang sudut sehingga susana di dalam kelas menjadi lebih terkesan dan peserta didik menjadi semakin paham dengan macam-macam sudut

Hasil penelitian secara keseluruhan pada pembelajaran siklus II menunjukkan adanya peningkatan terhadap hasil belajar peserta didik yang dilihat melalui hasil tes peserta didik yang dilaksanakan tiap akhir pertemuan. Pada siklus II hasil evaluasi telah mencapai kriteria keberhasilan yaitu 87,50\% peserta didik dari 16 peserta didik kelas IV yang berarti terjadi peningkatan sebesar $37,50 \%$ dari siklus I. Oleh karena itu, penelitian dihentikan pada siklus II karena telah puas sesuai dengan hasil yang dicapai yaitu nilai mencapai atau lebih dari 75\% nilai yang sesuai dengan KKM yang diharapkan yaitu 70 . Peningkatan keaktifan peserta didik juga terlihat dalam kegiatan pembelajaran dan antusias mereka. Hal tersebut menunjukkan adanya respon positif dari peserta didik dalam mengikuti pembelajaran matematika dengan menerapkan metode discovery

Dengan demikian, berdasarkan hasil observasi dan nilai rata-rata kelas pada pra tindakan, siklus I dan siklus II dapat diketahui perkembangan hasil belajar peserta didik 
dan apa yang diharapkan dalam penelitian ini dapat diketahui keberhasilannya. Sebagaimana hipotesis tindakan yang berbunyi " melalui penerapan metode discovery maka hasil belajar matematika pada peserta didik kelas IV SD Negeri 04 Wanggarasi dapat ditingkatkan" ternyata terbukti.

\section{KESIMPULAN}

Pembelajaran menerapkan metode discovery dengan guru menempelkan gambar di papan tulis dalam menjelaskan materi dapat meningkatkan hasil belajar peserta didik kelas IV SD Negeri 04 Wanggarasi pada mata pelajaran matematika. Hal tersebut terbukti dengan adanya peningkatan persentase KKM peserta didik secara klasikal. Pada pra tindakan persentase KKM peserta didik secara klasikal yaitu 25\%. Pada siklus I persentase KKM peserta didik secara klasikal sebanyak 50\% yang berarti terjadi peningkatan sebesar $25 \%$ dari pra tindakan. Sedangkan pada siklus II persentase KKM peserta didik secara klasikal yaitu $87,50 \%$ yang berarti terjadi peningkatan sebesar $37,50 \%$ dari siklus I dimana persentase tersebut telah mencapai target yang diinginkan yaitu minimal KKM peserta didik kelas IV SD Negeri 04 Wanggarasi secara klasikal adalah $75 \%$.

\section{DAFTAR PUSTAKA}

Arief S. Sadiman dkk. (1996). Media Pendidikan, Pengertian, Pengembangan dan Pemanfaatannya. Jakarta: PT Raja Grafindo Persada.

Asri Budiningsih, C. (2004). Belajar dan Pembelajaran. Jakarta: Rineka Cipta. Azhar Arsyad. (2006). Media Pembelajaran. Jakarta: PT Raja Grafindo Persada.

Burhan Mustaqim dan Ary Astuty. (2008). Ayo Belajar Matematika. Pusat Perbukuan Departemen Pendidikan Nasional.

Ety Syarifah \& Mukh Doyin. (2008). Teknik Penyusunan Proposal Penelitian Tindakan Kelas. Semarang: Bandungan Institute.

Johar Permana dan Mulyani Sumantri. (1998). Strategi Belajar Mengajar. Departemen Pendidikan dan Kebudayaan Direktorat Jenderal Pendidikan Tinggi Proyek Pendidikan Guru Sekolah Dasar.

Latuheru. (1988). Media Pembelajaran Dalam Proses Belajar-Mengajar Masa Kini. Jakarta: Depdikbud Proyek Pengembangan Lembaga Pendidikan Tenaga Kependidikan.

Mudjiono \& Dimyati. (2006). Belajar dan Pembelajaran. Jakarta: Rineka Cipta.

Nana Sudjana. (2005). Penilaian Hasil Proses Belajar Mengajar. Bandung: Remaja Rosdakarya.

Nana Sudjana dan Achmad Rivai. (1997). Media Pengajaran. Bandung: CV.Sinar Baru. Purwanto. (2010). Evaluasi Hasil Belajar. Yogyakarta: Pustaka Pelajar

Suharsimi Arikunto. (2002). Prosedur Penelitian (Suatu Pendekatan Praktek). Jakarta: Rineka Cipta.

Zainal Aqib, dkk. (2009). Penelitian Tindakan Kelas. Bandung: CV. Yrama Widya 